\title{
Epidemiology of staphylococcal infections
}

\author{
BY LEONARD ROODYN \\ General Practitioner, Woodberry Down Health Centre, Medical Officer in Charge, \\ Inoculation Clinic, Hospital for Tropical Diseases, N.W. 1
}

(Received 12 August 1959)

\section{INTRODUCTION}

Although staphylococcal infections form one of the commonest bacterial infections in the general population (Logan, 1954), they account for a very small percentage of admissions to a general hospital (Florey \& Ungehauer, 1958). In hospitals, they occur in surgical wards and maternity units and many patients admitted to such places acquire staphylococcal lesions. Epidemiological studies carried out in hospitals may not necessarily reflect the natural history of such infections in the general population. First, the patients admitted to hospital may already be ill and the question of lowered resistance and increased susceptibility to staphylococcal infections may arise. Secondly, in the complex hospital communities there is so much going and coming of personnel-patients, doctors, nurses, cleaners-that it may be difficult to establish any conclusion on the transmission of staphylococcal infection from person to person.

In contrast, the investigation of staphylococcal infections in the relatively small family unit, as seen in a general medical practice, reduces the problem to simpler proportions.

In a previous paper (Roodyn, 1954) families were described in which multiple cases of staphylococcal infection were observed during the years 1951-53. In this paper, the results of a 7-year period of follow-up are reported. This has revealed that in certain families repeated cross-infection has continued and strains of staphylococci, which were first noticed in 1951 or 1952, could still be recovered from staphylococcal lesions in the family up to 7 years later.

The total of families with multiple staphylococcal infections has now risen to seventeen, but in six of these families more than one strain of staphylococcus was at work and communication of infection from one member of the family to another could not be shown.

\section{MATERIAL AND METHODS}

The families lived under good social conditions on the Woodberry Down Estate, London, and attended the Woodberry Down Health Centre. Their lesions, boils and styes, were of relatively minor severity and no patient required admission to hospital on account of staphylococcal infection. The period of study was from 1951 to 1958 (July). Whenever a patient presented with a suspected staphyloccal infection, swabs were taken from the lesion and one nostril. Cultural examinations, coagulase production, antibiotic sensitivity and phage typing of the strains isolated were performed at the Central Public Health Laboratory, Colindale. A record was 
kept of any subsequent infection in the patient or other members of his family, but no tests were performed on other members of the family unless they came to the surgery with a staphylococcal lesion.

\section{OBSERVATIONS \\ Cross-infection in the family}

In eleven of the seventeen families there was spread of infection from one person to another in the same household. Two of these families had been under observation since 1952. They were described in 1954 but, as the period of follow-up was relatively short, they are now described more fully (see Figs. 1 and 2, and Table 1) and other examples of familial staphylococcal infection are recorded in Table 1.

Table 1. Eleven families with case to case spread of staphylococci

\begin{tabular}{|c|c|c|c|c|c|c|}
\hline $\begin{array}{c}\text { Family } \\
\text { no. }\end{array}$ & Name & Relationship & Age & Date & Lesion & $\begin{array}{l}\text { Phage } \\
\text { type or } \\
\text { pattern }\end{array}$ \\
\hline \multirow[t]{10}{*}{1} & Y.S. & Mother & 31 & 6. v. 52 & $\begin{array}{l}\text { Boil of chin } \\
\text { N/S }\end{array}$ & $\begin{array}{l}52 \mathrm{~A} / 79 \\
52 \mathrm{~A} / 79\end{array}$ \\
\hline & & & & 24. vịi. 52 & $\begin{array}{l}\text { Boil of leg } \\
\text { N/S }\end{array}$ & $\begin{array}{l}52 \mathrm{~A} / 79 \\
52 \mathrm{~A} / 79\end{array}$ \\
\hline & & & & 12. ix. 58 & $\begin{array}{l}\text { Wound of finger } \\
\text { N/S }\end{array}$ & $\begin{array}{l}52 \mathrm{~A} / 79 \\
52 \mathrm{~A} / 79\end{array}$ \\
\hline & M.S. & Daughter & 13 & 19. iv. 53 & $\begin{array}{l}\text { Boil of leg } \\
\text { N/S }\end{array}$ & $\begin{array}{l}52 \mathrm{~A} / 79 \\
52 \mathrm{~A} / 79\end{array}$ \\
\hline & A.S. & Father & 39 & 30. vii. 53 & $\begin{array}{l}\text { Abscess of axilla } \\
\mathrm{N} / \mathrm{S}\end{array}$ & $\begin{array}{l}52 \mathrm{~A} / 79 \\
52 \mathrm{~A} / 79\end{array}$ \\
\hline & & & & 11. vii. 57 & $\begin{array}{l}\text { Boil of axilla } \\
N / S\end{array}$ & $\begin{array}{l}52 \mathrm{~A} / 79 \\
52 \mathrm{~A} / 79\end{array}$ \\
\hline & & & & 10. vii. 58 & Boil of R. armpit & $52 \mathrm{~A} / 79$ \\
\hline & A.S. & Daughter & 17 & 16. vii. 57 & Abscess of eyelid & $52 \mathrm{~A} / 79$ \\
\hline & G.S. & Son & 12 & 21. xi. 55 & $\begin{array}{l}\text { Boil of arm } \\
\text { N/S }\end{array}$ & $\begin{array}{l}52 \mathrm{~A} / 79 \\
52 \mathrm{~A} / 79\end{array}$ \\
\hline & & & & $\begin{array}{l}\text { 21. iv. } 58 \\
20 . \text { vii. } 58\end{array}$ & $\begin{array}{l}\text { Boil of nostril } \\
\text { Abscess of eyelid }\end{array}$ & $\begin{array}{l}52 \mathrm{~A} / 79 \\
52 \mathrm{~A} / 79\end{array}$ \\
\hline \multirow[t]{7}{*}{2} & E.G. & Daughter & 14 & 29. ix. 51 & $\begin{array}{l}\text { Abscess of finger } \\
N / S\end{array}$ & $\begin{array}{l}3 \mathrm{~B} / 3 \mathrm{C} \\
3 \mathrm{~B} / 3 \mathrm{C}\end{array}$ \\
\hline & & & & 19. iii. 53 & $\begin{array}{l}\text { Boil of R. axilla } \\
\text { N/S }\end{array}$ & $\begin{array}{l}3 \mathrm{~B} / 3 \mathrm{C} \\
3 \mathrm{~B} / 3 \mathrm{C}\end{array}$ \\
\hline & & & & 21. iv. 53 & $\begin{array}{l}\text { Boil of R. axilla } \\
\text { N/S }\end{array}$ & $\begin{array}{l}3 \mathrm{~B} / 3 \mathrm{C} \\
\mathbf{3 B} / \mathbf{3 C}\end{array}$ \\
\hline & & & & 23. xii. 56 & $\begin{array}{l}\text { Abscess of eyelid } \\
\text { N/S }\end{array}$ & $\begin{array}{l}3 \mathrm{~B} / 3 \mathrm{C} \\
\mathbf{3 B} / \mathbf{3 C}\end{array}$ \\
\hline & & & & 17. iii. 58 & $\begin{array}{l}\text { Boil of face } \\
\text { N/S }\end{array}$ & $\begin{array}{l}3 \mathrm{~B} / 3 \mathrm{C} \\
3 \mathrm{~B} / 3 \mathrm{C}\end{array}$ \\
\hline & E.G. & Mother & 40 & $\begin{array}{l}\text { 29. ix. } 51 \\
\text { 21. iv. } 53\end{array}$ & $\begin{array}{l}\text { Boil of R. axilla } \\
\text { Boil of nostril }\end{array}$ & $\begin{array}{l}3 \mathrm{~B} / 3 \mathrm{C} \\
3 \mathrm{~B} / 3 \mathrm{C}\end{array}$ \\
\hline & D.G. & Brother & 10 & 21. iv. 53 & $\begin{array}{l}\text { Boil of axilla } \\
N / S\end{array}$ & $\begin{array}{l}3 B / 3 C \\
3 B / 3 C\end{array}$ \\
\hline
\end{tabular}


Table 1 (cont.)

\begin{tabular}{|c|c|c|c|c|c|c|}
\hline $\begin{array}{l}\text { Family } \\
\text { no. }\end{array}$ & Name & Relationship & Age & Date & Lesion & $\begin{array}{l}\text { Phage } \\
\text { type or } \\
\text { pattern }\end{array}$ \\
\hline \multirow[t]{5}{*}{3} & \multirow[t]{3}{*}{ M.V. } & \multirow[t]{3}{*}{ Son } & \multirow[t]{3}{*}{13} & 27. ii. 52 & $\begin{array}{l}\text { Boil of elbow } \\
\text { N/S }\end{array}$ & $\begin{array}{l}\text { No lysis } \\
\text { No lysis }\end{array}$ \\
\hline & & & & 12. iii. 53 & $\begin{array}{l}\text { Boil of face } \\
\text { N/S }\end{array}$ & $\begin{array}{l}\text { No lysis } \\
\text { No lysis }\end{array}$ \\
\hline & & & & 4. iv. 57 & $\begin{array}{l}\text { Boil of face } \\
\text { N/S }\end{array}$ & $\begin{array}{l}\text { No lysis } \\
\text { No lysis }\end{array}$ \\
\hline & M.V. & Mother & 44 & 14. i. 53 & $\begin{array}{l}\text { Boil of finger } \\
\text { N/S }\end{array}$ & $\begin{array}{l}\text { No lysis } \\
\text { No lysis }\end{array}$ \\
\hline & H.V. & Father & 42 & 11. xii. 52 & $\begin{array}{l}\text { Boil of leg } \\
\text { N/S }\end{array}$ & $\begin{array}{l}\text { No lysis } \\
\text { No lysis }\end{array}$ \\
\hline \multirow[t]{2}{*}{4} & T.B. & Brother & 14 & 22. iii. 52 & $\begin{array}{l}\text { Boil of abdomen } \\
\mathrm{N} / \mathrm{S}\end{array}$ & $\begin{array}{l}3 \mathrm{C} \\
42 \mathrm{C}\end{array}$ \\
\hline & S.B. & Sister & 2 & 19. vi. 52 & $\begin{array}{l}\text { Boil of buttock } \\
\text { N/S }\end{array}$ & $\begin{array}{l}3 \mathrm{C} \\
55\end{array}$ \\
\hline \multirow[t]{2}{*}{5} & S.T. & Sister & 16 & 12. xii. 51 & $\begin{array}{l}\text { Stye } \\
\mathrm{N} / \mathrm{S}\end{array}$ & $\begin{array}{l}3 \mathrm{C} / 55 \\
3 \mathrm{C} / 55\end{array}$ \\
\hline & L.T. & Brother & 22 & 17. vi. 52 & $\begin{array}{l}\text { Boil of R. knee } \\
\text { N/S }\end{array}$ & $\begin{array}{l}3 \mathrm{C} / 55 \\
3 \mathrm{C} / 55\end{array}$ \\
\hline \multirow[t]{2}{*}{6} & L.K. & Daughter & 5 & 30. viii. 52 & Stye & $3 \mathrm{C} / 55$ \\
\hline & H.K. & Father & 30 & 3. ix. 52 & $\begin{array}{l}\text { Boil of forearm } \\
\text { N/S }\end{array}$ & $\begin{array}{l}3 \mathrm{C} / 55 \\
3 \mathrm{C} / 55\end{array}$ \\
\hline \multirow[t]{2}{*}{7} & M.M. & Father & 25 & 14. v. 53 & $\begin{array}{l}\text { Stye } \\
\text { N/S }\end{array}$ & $\begin{array}{l}3 \mathrm{C} / 55 \\
3 \mathrm{C} / 55\end{array}$ \\
\hline & B.M. & Daughter & 4 & 28. viii. 53 & $\begin{array}{l}\text { Boil of buttock } \\
\text { N/S }\end{array}$ & $\begin{array}{l}3 \mathrm{C} / 55 \\
\mathbf{3 C} / 55\end{array}$ \\
\hline \multirow[t]{3}{*}{8} & R.G. & Mother & 46 & 16. iv. 57 & Boil of nose & $3 \mathrm{C} / 71$ \\
\hline & P.G. & Son & 12 & 16. iv. 57 & Boil of nose & $3 \mathrm{C} / 71$ \\
\hline & B.G. & Father & 48 & 23. xi. 57 & $\begin{array}{l}\text { Boil of groin } \\
\text { N/S }\end{array}$ & $\begin{array}{l}3 \mathrm{C} / 71 \\
3 \mathrm{C} / 71\end{array}$ \\
\hline \multirow[t]{2}{*}{9} & м.H. & Daughter & 12 & 19. ix. 57 & $\begin{array}{l}\text { Boil of neck } \\
\text { N/S }\end{array}$ & $\begin{array}{l}52 / 79 / 80 \\
52 / 79 / 80\end{array}$ \\
\hline & M.H. & Mother & 63 & 28. ix. 57 & $\begin{array}{l}\text { Boil of arm } \\
\text { N/S }\end{array}$ & $\begin{array}{l}52 / 79 / 80 \\
52 / 79 / 80\end{array}$ \\
\hline \multirow[t]{2}{*}{10} & A.D. & Son & $\begin{array}{c}2 \\
\text { months }\end{array}$ & 11. v. 57 & $\begin{array}{l}\text { Boil of buttock } \\
\text { N/S } \\
\text { Anal swab }\end{array}$ & $\begin{array}{l}52 \mathrm{~A} / 80 \\
52 \mathrm{~A} / 80 \\
52 \mathrm{~A} / 80\end{array}$ \\
\hline & M.D. & Mother & 30 & 17. v. 57 & $\begin{array}{l}\text { Boil of leg } \\
\text { N/S }\end{array}$ & $\begin{array}{l}52 \mathrm{~A} / 80 \\
52 \mathrm{~A} / 80\end{array}$ \\
\hline \multirow[t]{2}{*}{11} & I.C. & Daughter & $\begin{array}{c}3 \\
\text { weeks }\end{array}$ & 15. iv. 57 & $\begin{array}{l}\text { Boil } \\
\text { N/S }\end{array}$ & $\begin{array}{l}79 \\
79\end{array}$ \\
\hline & M.C. & Mother & 29 & 19. viii. 57 & $\begin{array}{l}\text { Boil of face } \\
\text { N/S }\end{array}$ & $\begin{array}{l}79 \\
79\end{array}$ \\
\hline
\end{tabular}


Once introduced into a household, the staphylococci showed remarkable powers of persistence. For instance, in families no. 1 and no. 2 ( see Table 1 and figs. 1 and 2) the same strains of staphylococci remained with the respective families for over 6 years. That is to say, all the cultures of Staph. aureus isolated at different times during this period from the various members of the two families reproduced exactly the respective phage patterns noted when the original cultures were isolated in 1951 and 1952.

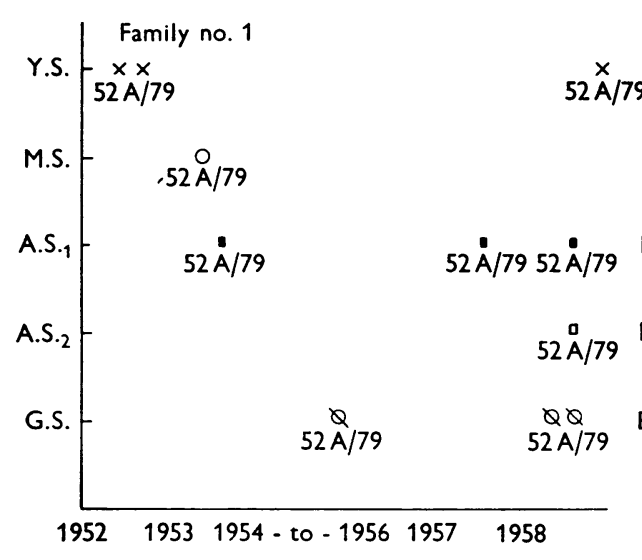

Fig. 1

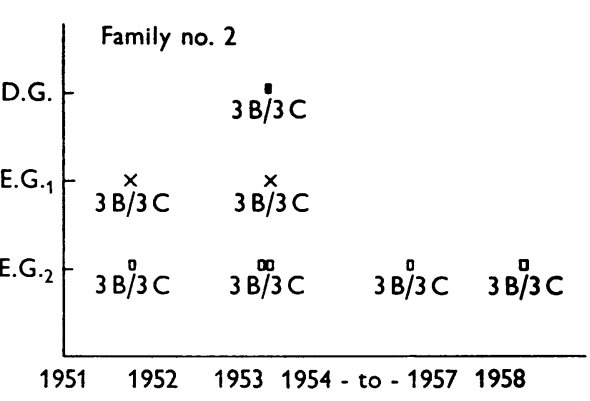

Fig. 2

Fig. 1. Family no. 1. Repeated cross-infection with Staph. aureus phage type 52A/79 over a period of 6 years. Y.S., mother $=x \times:$ M.S., daughter $=0$ : A.S., father $=\square$ : A.S.

Fig. 2. Family no. 2. Repeated cross-infection with Staph. aureus phage type 3B/3C. D.G., brother $=$ a; E.G.1, mother $=x$; E.G.2, daughter $=\square$.

In both these families one member of the household was particularly prone to recurrent lesions over the years. In the first, the father (A.S.) had recurrent boils of the axilla and in the second, the daughter (E.G.) had recurrent boils and styes. Although both these patients were nasal carriers, it was only when they developed frank staphylococcal lesions that other cases were observed in that family. Thus it was the patient with a long history of staphylococcal lesions who appeared to be the source of infection to the other members of the household.

\section{The dissemination of hospital-acquired strains of staphylococci}

Rarely only was it possible to find the origin of a strain of staphylococcus introduced into a family. In one instance, however, it was clear that a strain of Staph. aureus acquired by an infant in a maternity hospital was later passed on to the mother.

I.C. Age 3/52. 15. iv. 57 (Family no. 11; Table 1). This infant was born in a local maternity hospital and she had developed a staphylococcal infection of the nail bed and a few septic spots on the face. Swabs from the pus yielded penicillinresistant Staph. aureus, phage type 79. The nasal swab also yielded penicillin- 
resistant Staph. aureus type 79. Four months later, 19. viii. 57, the mother, for the first time in her life, developed boils on the face. Swabs from a boil and from the nose yielded penicillin-resistant Staph. aureus, phage type 79 .

\section{Interval between infections}

In Fig. 3 is recorded the interval between the first infection encountered in a family and any subsequent infections in other members of the household. It was found that this interval was most irregular. For example, in two instances infections developed at the same time, yet in other cases 3 or 4 months elapsed before a subsequent infection developed; in some the interval was as long as 8-11 months. Generally, after a member of the household came to the surgery with a boil or stye it took 3-11 months before further cases in the same family were discovered.

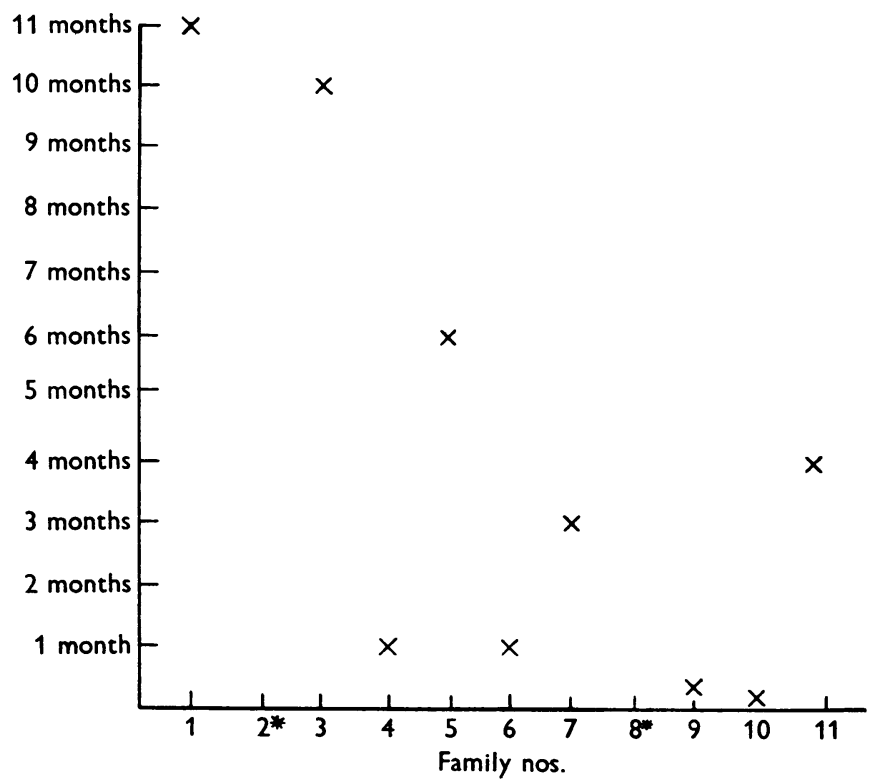

Fig. 3. Interval between first and subsequent infections in eleven families.

* = simultaneous.

\section{Phage types of strains in familial infections}

The phage patterns of the strains isolated from the eleven families were as follows:

$\begin{array}{ll}\text { Group I (52/52A/79 etc. }) & 4 \\ \text { Group II (3B/3C/55/71 etc.) } & 6 \\ \text { Group III }(42 / 52 / 53 / 75 \text { etc. }) & 0 \\ \text { No lysis } & 1\end{array}$

Although it is appreciated that the somewhat increased frequency of the Lytic Group II strains, found in these family studies, cannot, with the small numbers involved, be regarded as significant, it was a fact that at the time when these families were first affected (1951-53), the prevalent types of staphylococci in the 
general community belonged to the Lytic Group II. In recent years, however, staphylococci with the phage pattern $3 \mathrm{~B} / 3 \mathrm{C} / 55 / 71$ appear to be less frequently encountered. My own figures indicate that whereas in 1951-53 Group II strains accounted for $43 \%$ of all the penicillin sensitive strains isolated from boils and styes, in 1957-58 only $29 \%$ of the isolations from new clinical cases of the same nature fell into this Lytic Group.

It is not suggested that strains other than those of Group II showed any less powers of persistence. Thus, a strain 52A/79 persisted for 6 years in the first family described, and in family no. 3 another strain resistant to lysis remained in this household for a similar period.

There was no evidence from these studies of cross-infection in families that any particular phage type of staphylococcus had greater powers of communicability or persistence than another.

At the time of writing, there had been no examples of infection by the 'epidemic strain' 80/81 first described by Rountree \& Freeman (1955).

\section{Multiple cases without cross-infection}

The presence of multiple cases of staphylococcal infection in a family did not necessarily imply communication of a strain of staphylococcus from patient to patient. In six of the seventeen families, although there were multiple cases, the lesions were caused by different phage types of staphylococci, so that crossinfection was excluded. The results of phage-typing in these families are recorded in Table 2.

In this table it will be noted that one large family (no. 12), in which there were four daughters and two sons, shows an epidemiological picture of considerable complexity. Infections were caused by no less than three different phage types of staphylococci at different times, and it was clear that although there were frequent and multiple cases of boils and styes in the household there was no cross-infection (Fig. 4).

\section{DISCUSSION}

Even in the comparative simplicity of a single household, the epidemiology of staphylococcal infections appears baffling.

The fact that more than one case of boils or styes developed in a family did not necessarily indicate a patient-to-patient spread of infection. Thus in six of the seventeen families in this investigation in which multiple infections occurred, cross-infection was excluded by the isolation of different phage types of staphylococci from the infected persons. In one family, no less than three different strains of staphylococci were responsible for lesions in the different members.

Staphylococcal infections are so common in the general population, that coincident or independent infections with different strains in a single family were by no means unusual. Similarly, it can be assumed that in large surgical wards or maternity units, some of the multiple infections are in fact coincidental and are not associated with communication of strains.

In eleven of the seventeen families, however, there was evidence of person-toperson spread of staphylococci. Such cross-infection involves first, a source of 
Table 2. Multiple staphylococcal infections in families without case-to-case spread

\begin{tabular}{|c|c|c|c|c|c|c|}
\hline $\begin{array}{l}\text { Family } \\
\text { no. }\end{array}$ & Name & Relationship & Age & Date & Lesion & $\begin{array}{l}\text { Phage type } \\
\text { or pattern }\end{array}$ \\
\hline \multirow[t]{4}{*}{12} & C.B. & Sister & 11 & $\begin{array}{l}\text { 29. xii. } 51 \\
\text { 14. xi. } 52\end{array}$ & $\begin{array}{l}\text { Boil } \\
\text { Boil }\end{array}$ & $\begin{array}{l}52 \mathrm{~A} \\
52 \mathrm{~A}\end{array}$ \\
\hline & E.B. & Sister & 19 & $\begin{array}{l}\text { 29. i. } 52 \\
\text { 31. iii. } 52\end{array}$ & $\begin{array}{l}\text { Stye } \\
\text { Boil }\end{array}$ & $\begin{array}{l}3 B \\
\text { 3B }\end{array}$ \\
\hline & P.B. & Sister & 17 & $\begin{array}{l}\text { 28. ii. } 52 \\
9 . \text { vii. } 52\end{array}$ & $\begin{array}{l}\text { Boil } \\
\text { Boil }\end{array}$ & - \\
\hline & M.B. & Sister & 18 & $\begin{array}{l}\text { 27. ix. } 52 \\
\text { 14. ix. } 52\end{array}$ & $\begin{array}{l}\text { Boil } \\
\text { Boil }\end{array}$ & $\begin{array}{l}52 \mathrm{~A} \\
52 \mathrm{~A}\end{array}$ \\
\hline \multirow[t]{2}{*}{13} & F.H. & Husband & 31 & 20. ii. 52 & $\begin{array}{l}\text { Boil of neck } \\
\text { N/S }\end{array}$ & $\begin{array}{l}71 \text { (weak } \\
\text { reaction) } \\
\text { No lysis }\end{array}$ \\
\hline & D.H. & Wife & 28 & 20. ii. 52 & $\begin{array}{l}\text { Boil of upper arm } \\
\mathrm{N} / \mathrm{S}\end{array}$ & $\begin{array}{l}\text { 52A } \\
\text { No } \\
\text { staphylococci }\end{array}$ \\
\hline \multirow[t]{2}{*}{14} & K.B. & Sister & 13 & 13. x. 52 & $\begin{array}{l}\text { Boil } \\
\text { N/S }\end{array}$ & $\begin{array}{l}52 / 52 \mathrm{~A} \\
52 / 52 \mathrm{~A}\end{array}$ \\
\hline & A.B. & Brother & 18 & 23. xi. 55 & $\begin{array}{l}\text { Boil } \\
\text { N/S }\end{array}$ & $\begin{array}{l}3 \mathrm{C} / 55 / 71 \\
\text { No lysis }\end{array}$ \\
\hline \multirow[t]{2}{*}{15} & T.E. & Mother & 38 & 14. viii. 57 & $\begin{array}{l}\text { Boil } \\
\text { N/S }\end{array}$ & $\begin{array}{l}\text { No lysis } \\
\text { No lysis }\end{array}$ \\
\hline & J.E. & Son & 14 & 30. iv. 58 & $\begin{array}{l}\text { Abscess } \\
\text { N/S }\end{array}$ & $\begin{array}{l}6 / 7 / 54 / 70 / 73 \\
\text { Not performed }\end{array}$ \\
\hline \multirow[t]{2}{*}{16} & W.R. & Father & 57 & 10. vi. 52 & $\begin{array}{l}\text { Boil } \\
\mathrm{N} / \mathrm{S}\end{array}$ & $\begin{array}{l}\text { 52A } \\
\text { No lysis }\end{array}$ \\
\hline & A.R. & Daughter & 19 & 1. vii. 57 & Boil of nostril & $79 / 80 / 7 / 54$ \\
\hline \multirow[t]{2}{*}{17} & R.F.H. & Mother & 29 & 17. vi. 52 & $\begin{array}{l}\text { Boil } \\
\text { N/S }\end{array}$ & $\begin{array}{l}52 \mathrm{~A} \\
52 \mathrm{~A}\end{array}$ \\
\hline & J.H. & Son & 8 & 9. ix. 53 & $\begin{array}{l}\text { Boil } \\
\text { N/S }\end{array}$ & $\begin{array}{l}\text { No lysis } \\
\text { No } \\
\text { staphylococci }\end{array}$ \\
\hline
\end{tabular}

staphylococci in an individual and, secondly, the transmission of the organisms from that source to the recipient.

From the studies of familial cross-infection, it was apparent that the most important source of infection was the septic staphylococcal lesion-a boil or stye or folliculitis. In this respect, staphylococcal infection at home resembles hospital infection. For example, Barber, Csillag \& Medway (1958), in a recent report of an outbreak of an antibiotic resistant staphylococcal infection in a hospital, found that superficial skin lesions in one of the patients were the source of the epidemic strain. It was felt by these investigators that the nasal carrier state played little part in the dissemination of the epidemic strain, which confirmed earlier work by Barber \& Burston (1955). 
It has been found from a study of patients with recurrent staphylococcal infections that staphylococci can persist in areas of the skin for many years after the lesion has healed. Such patients may act as a constant source of infection to other members of their family. In two of the families studied for over 6 years, the patients with recurrent lesions, and probably chronic skin and nasal carriage, were mainly responsible for multiple infections in the household.

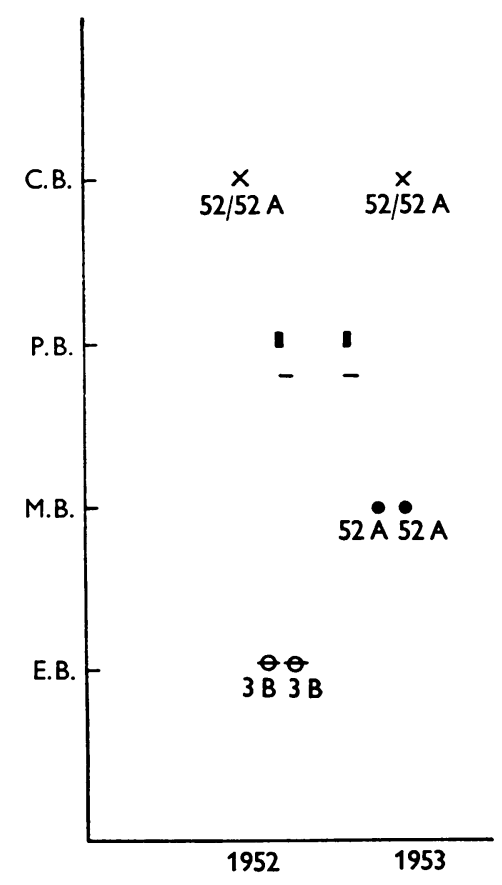

Fig. 4. Multiple staphylococcal lesions in a family caused by three different strains of Staph. aureus. - = no phage lysis.

The time interval between the recognition of the index case of infection and the secondary case in the family contact was most irregular. In a few instances simultaneous infection was observed and in other examples 2-10 months elapsed before subsequent infections were observed in other members of the family.

This suggested that the mode of transmission was an indirect one and tended to confirm the experimental work of Duguid \& Wallace (1948). By measurements of the bacterial contamination of the air, they found that the liberation of infected dust particles from the skin and personal clothing was relatively much more important than droplet spread from the nasal cavities by sneezing.

From the source of staphylococci in the septic lesion, there is then an extensive contamination of the skin and clothes. Body movement liberates dust particles bearing staphylococci into the air; Colebrook \& Bourdillon (1946), for example, showed that shaking pyjamas resulted in bacterial contamination of the air with staphylococci. The air and inaminate objects become infected with staphylococci and the latter may remain infective many months. Infection of the skin of the 
recipient finally takes place by contact with inanimate objects or from contaminated air. Such an indirect chain of events would explain the lengthy and irregular interval between cases in a household.

In these studies, staphylococci of group II with a phage pattern $3 \mathrm{~B} / 3 \mathrm{C} / 55$ were more commonly encountered. This probably reflected their high frequency in the years 1950-53 when they were first introduced into the households under study.

It was most unlikely that group II strains possessed greater powers of communicability because familial infections with other strains were also found.

Since about 1953, however, there has been a change in the frequency distribution of the different phage patterns of staphylococci isolated from the general population. Group I strains, with their higher incidence of drug resistance, have now become more common. A similar change has also occurred in the predominant phage patterns isolated from hospital infections.

Blair \& Carr (1958) reported that, prior to 1954, group III strains predominated in hospital-acquired infections in the U.S.A. Since that year, in their hospital, group III strains had dropped to $26 \%$ and staphylococci of phage $80 / 81$ now predominated.

At the time of writing (1959), no infections have been encountered in the general population in which the so-called 'epidemic strain', phage types 80/81, was responsible. This is not to say that dissemination of hospital-acquired strains into the general population does not occur. It is probably a fairly frequent occurrence for even in a single practice there was a family in which this happened. In this particular example, 4 months elapsed before the hospital strain appeared in another member of the household.

\section{SUMMARY}

During the period 1951-58, a study has been carried out of a series of seventeen families in which more than one member developed a staphylococcal lesion.

In eleven of these families, phage typing revealed that spread of infection from person to person had occurred. Once introduced into a household, the staphylococcus demonstrated great persistence; a particular strain could cause recurrent lesions in different members for as long as 6 years. The interval between the first and subsequent infection in another member of the same family was most irregular, but was usually $2-11$ months.

The patient with recurrent furunculosis appeared to be mainly responsible for dissemination of strains.

In six out of the seventeen families, although multiple infections were encountered in the household, these were not due to case-to-case spread because more than one phage type of staphylococcus was isolated.

In one family investigated, there had been a dissemination of a hospitalacquired staphylococcus to another member of the household.

No infections were encountered in which the 'epidemic strain' $80 / 81$ was responsible.

I wish to express my gratitude to Dr R. E. O. Williams of the Staphylococcal Reference Laboratory, Colindale, for his assistance in this work. 


\section{REFERENCES}

Barber, M. \& BURSTON, J. (1955). Lancet, ii, 578.

Barber, M., Csmlag, A. \& Medway, A. J. (1958). Brit. med. J. ii, 1377.

BLAIR, J. E. \& CARR, M. (1958). Staphylococci in hospital-acquired infections. J. Amer. med. Ass. 166, 1192.

Bourdmlon, R. B. \& Colebrook, L. (1946). Lancet, i, 561, 601.

DugUID, J. P. \& WALlaCE, A. T. (1948). Lancet, ii, 845.

Florey, M. E. \& Ungehauer, V. (1958). Brit. med. $J$. ii, 403.

Logan, W. P. (1954). Practitioner, 173, 188.

Roodyn, L. (1954). Brit. med. J. ii, 1322.

Rountree, P. M. \& Freeman, B. M. (1955). Med. J. Aust. ii, 157. 